\author{
๑Ю. О. Чемерис, В. І. Перцов, О. М. Бойцова, І. Г. Денисенко ${ }^{1}$ \\ Запорізъкий державний медичний університет \\ ${ }^{1}$ КНП «Місъка дитяча лікарня № 5 Запорізъкої місъкої ради»
}

\title{
ДОСВІД ВИКОРИСТАННЯ РАЦІОНАЛЬНОЇ АНТИБАКТЕРІАЛЬНОЇ ТЕРАПІї В ЛІКУВАННІ НОВОНАРОДЖЕНИХ ДІТЕЙ У ВІДДІЛЕННІ ІНТЕНСИВНОЇ ТЕРАПІЇ
}

Мета дослідження - встановити кількісний і якісний склад мікрофолори верхніх дихальних шляхів новонароджених пацієнтів та визначити чутливість її до антибактеріальних препаратів.

Матеріали та методи. Проведено мікробіологічне дослідження посівів із верхніх дихальних шляхів та визначення чутливості мікрофлори до антибактеріальних препаратів у 201 пацієнта, які були госпіталізовані та проліковані у відділенні анестезіології та інтенсивної терапії новонароджених дітей КНП «Міська дитяча лікарня № 5 Запорізької міської ради». Дослідження проводились при госпіталізації хворого до відділення, надалі посіви здійснювали кожні 7 днів.

Результати дослідження та їх обговорення. Достатню чутливість грампозитивних мікроорганізмів, які переважали в посівах на всіх етапах дослідження, виявили до ванкоміцину, деяких карбапенемів, лінезоліду, кліндаміцину протягом всього дослідження. При дослідженні чутливості грамнегативної мікрофрлори до антибіотиків виявилась висока чутливість до сучасних захищених пеніцилінів, карбапенемів, аміноглікозидів, орторхінолонів, а при вивченні чутливості у повторних посівах із верхніх дихальних шляхів пацієнтів виявлено, що досить висока чутливість зберігається до карбапенемів та аміноглікозідів.

Висновки. Грампозитивні мікроорганізми переважали в мікробіологічних дослідженнях як при госпіталізації, так і при вторинних дослідженнях. Застосування антибактеріальної терапії з урахуванням чутливості фрлори є запорукою швидшого покращення клініко-біологічних показників пацієнта і, як наслідок, скорочення терміну перебування у відділенні інтенсивної терапії.

Ключові слова: новонароджені діти; антибактеріальна терапія; відділення анестезіології та інтенсивної терапії новонароджених дітей; грампозитивні мікроорганізми; грамнегативні мікроорганізми.

ОПЫТ ИСПОЛЬЗОВАНИЯ РАЦИОНАЛЬНОЙ АНТИБАКТЕРИАЛЬНОЙ ТЕРАПИИ В ЛЕЧЕНИИ НОВОРОЖДЕННЫХ ДЕТЕЙ В ОТДЕЛЕНИИ ИНТЕНСИВНОЙ ТЕРАПИИ

Цель исследования - установить количественный и качественный состав микрофлоры верхних дыхательных путей новорожденных пациентов и определить чувствительность ее к антибактериальным препаратам.

Материалы и методы. Проведено микробиологическое исследование посевов с верхних дыхательных путей и определение чувствительности микрофрлоры к антибактериальным препаратам у 201 пациента, которые были госпитализированы и пролечены в отделении анестезиологии и интенсивной терапии новорожденных детей кНП «Городская детская больница № 5 Запорожского городского совета». Исследования проводились при госпитализации больного в отделение, в дальнейшем посевы проводились каждые 7 дней.

Результаты исследования и их обсуждение. Была обнаружена достаточная чувствительность грамположительных микроорганизмов, которые преобладали в посевах на всех этапах исследования, к ванкомицину, некоторым карбапенемам, линезолиду, клиндамицину на протяжении всего исследования. При исследовании чувствительности граммотрицательной микрофрлоры к антибиотикам выявилась высокая чувствительность к современным защищенным пенициллинам, карбапенемам, аминогликозидам, фрторхинолонам, а при исследовании чувствительности в повторных посевах из верхних дыхательных путей пациентов установлено, что достаточно высокая чувствительность сохраняется к карбапенемам и аминогликозидам.

Выводы. Граммположительные микроорганизмы преобладали в микробиологических исследованиях как при поступлении, так и при вторичных исследованиях. Применение антибактериальной терапии с учетом чувствительности фрлоры является залогом более скорого улучшения клинико-биологических показателей пациента и, как следствие, сокращения срока пребывания в отделении интенсивной терапии.

ключевые слова: новорожденные дети; антибактериальная терапия; отделение анестезиологии и интенсивной терапии новорожденных детей; граммположительные микроорганизмы; граммотрицательные микроорганизмы.

USE EXPERIENCE OF RATIONAL ANTIBACTERIAL THERAPY IN THE TREATMENT OF NEWBORNS IN THE INTENSIVE CARE UNIT

The aim of the study - to establish the quantitative and qualitative composition of the microflora of the upper respiratory tract of newborn patients and to determine its sensitivity to antibacterial drugs.

Materials and Methods. A microbiological study of cultures from the upper respiratory tract and determination of the sensitivity of the microflora to antibacterial drugs in 201 patients who were hospitalized and treated in the Department of Anesthesiology and Intensive Care of Newborns of the City Children's Hospital No. 5 in Zaporizhzhia. The studies were performed during the hospitalization of the patient to the department, then inoculations were performed every 7 days.

Results and Discussion. Sufficient sensitivity of Gram-positive microorganisms, which prevailed in inoculation at all stages of the study, was found to vancomycin, some carbopenems, linezolid, clindamycin throughout the study. The study of Gram-negative microflora sensitivity to antibiotics revealed a high sensitivity to modern protected penicillins, carbapenems, aminoglycosides, fluoroquinolones, and in the study of sensitivity in repeated inoculations, repeated susceptibility was observed to carbapenems, aminoglycosides. 
Conclusions. Gram-positive microorganisms predominated in microbiological studies, both in hospitalization and in secondary studies. The use of antibacterial therapy taking into account the sensitivity of the flora is the key to faster improvement of clinical and biological parameters of the patient and, as a consequence, reduce the length of stay in the intensive care unit.

Key words: newborns; antibacterial therapy; department of anesthesiology and intensive care of newborns; Gram-positive microorganisms; Gram-negative microorganisms.

ВСтУП. Внутрішньоутробна інфекція є однією з найбільш поширених причин захворюваності й смертностіу дітей в неонатальному періоді, таким чином, інсрекційна патологія була і залишається однією з актуальних проблем неонатології [1].

На сьогодні підставою для розробки раціональної стратегії застосування антибактеріальних препаратів $€$ проведення мікробіологічних досліджень. Отримані в результаті мікробіологічного дослідження дані про наявність і кількість штамів мікроорганізмів з урахуванням виявленої до них чутливості антибактеріальних препаратів $€$ основою для призначення антибіотиків $[2,3,6,25]$.

Використання антибактеріальних препаратів у медичній практиці привело до зниження ускладнень та летальності при найбільш поширених та тяжких захворюваннях. Проте на фроні надмірного і часом необґрунтованого застосування антибактеріальних препаратів для просрілактики або як засобів самолікування, використання у сільському господарстві тощо з'явились мікроорганізми, резистентні до багатьох антибіотиків $[4,23,24]$. Тому стартова антибактеріальна терапія має призначатися емпірично, враховуючи ймовірного збудника, при суворому дотриманні дозування і кратності призначення препарату й врахуванні наявності супутньої патології, яка може вплинути на фрармакокінетику антибактеріального препарату $[1,4,6,7,18,22]$.

За інших рівних умов слід вибирати антибактеріальний препарат найбільш вузького спектра активності, оскільки невиправдане застосування антибіотиків широкого спектра дії супроводжується високим ризиком селекції антибіотикорезистентних штамів патогенів та сапрофрітної мікрофлори, а також більш високим ризиком розвитку інших небажаних реакцій $[1,4,15]$.

МЕТА ДОсЛІДЖЕННЯ - Встановити кількісний і якісний склад мікрофрлори верхніх дихальних шляхів новонароджених пацієнтів та визначити чутливість ії̈ до антибактеріальних препаратів.

МАТЕРІАЛИ ТА МЕТОДИ. У роботі проведено аналіз 201 випадку лікування пацієнтів у відділенні анестезіології та інтенсивної терапії новонароджених дітей КНП «Міська дитяча лікарня № 5» 3МР протягом 2019 року. Більшість із них, а саме 111 дітей (55,2\%), були госпіталізовані із внутрішньоутробною інфекцією, із синдромом дихальних розладів - 41 дитина (20,4 \%), з уродженими вадами розвитку шлунково-кишкового тракту - 18 пацієнтів (9\%). Всі вони потребували призначення антибактеріальної терапії. Бактеріологічні дослідження посівів із верхніх дихальних шляхів пацієнта проводили при госпіталізації хворого до відділення (первинні посіви), надалі посіви здійснювали кожні 7 днів (вторинні посіви). Змиви з верхніх дихальних шляхів проводили за стандартною методикою з використанням транспортних пробірок для біологічних рідин із гелем та пластиковим аплікатором. Далі виконували пересів у чашки з живильним середовищем, а після виявлення росту колоній мікроорганізмів визначали чутливість фрлори до антибактеріальних препаратів за допомогою диско-диорузійного методу. Методи забору матеріалу та лабораторні дослідження проводили відповідно до наказів МОЗ України № 167 від 05.04.2007 р., № 170 від 15.04.2005 р., № 192 від 03.08.1999 р. та № 234 від 10.05.2007 р. Аналіз та систематизацію отриманих результатів бактеріологічних досліджень проводять у відділенні кожні 6 місяців; таким чином, за даними посівів біологічних матеріалів робиться висновок про динаміку позагоспітальної та нозокоміальної фрлори, а також приймається рішення про стартову антибактеріальну терапію за чутливістю мікроорганізмів.

РЕЗУЛЬТАТИ ДОСЛІДЖЕННЯ ТА ЇХ ОБГОВОРЕННЯ. Як первинні, так і вторинні посіви з верхніх дихальних шляхів новонароджених пацієнтів протягом 2019 року характеризувались переважанням грампозитивної фрлори, яка майже в 2 рази перевищує вміст грамнегативної. Так, якщо грампозитивних мікроорганізмів при первинних дослідженнях було виявлено 97 (65,1 \%), а при повторному дослідженні 259 (67,8 \%), то грамнегативна фрлора складала 52 (34,9 \%) при первинному обстеженні і 116 $(32,2$ \%) при повторних посівах (табл. 1).

Таблиця 1. Дані бактеріологічних досліджень

\begin{tabular}{|c|c|c|c|}
\hline \multicolumn{2}{|c|}{ Мікроорганізми } & Первинні посіви, \% & Вторинні посіви, \% \\
\hline \multirow[t]{7}{*}{ Грампозитивні } & Staph. haemolyticus & 42,8 & 50,1 \\
\hline & Streptococcus viridans & 14,6 & 10,0 \\
\hline & Enterococcus faecium & 2,6 & 2,9 \\
\hline & Staphylococcus aureus & 2,0 & 0,9 \\
\hline & Corynebacterium spp & 1,4 & 2,1 \\
\hline & Streptococcus agalactiae & 1,3 & 0,9 \\
\hline & Інші & 0,2 & 0,3 \\
\hline \multirow[t]{6}{*}{ Грамнегативні } & Klebsiella pneumoniae & 16,1 & 13,0 \\
\hline & Enterobacter cloacae & 7,4 & 7,7 \\
\hline & Escherichia coli & 6,0 & 0,9 \\
\hline & Pseudomonas aeruginosa & 3,4 & 4,4 \\
\hline & Acinetobacter baumannii & 2,0 & 6,3 \\
\hline & Інші & 0,2 & 0,5 \\
\hline
\end{tabular}


Серед найбільш поширених грампозитивних мікроорганізмів Staphylococcus haemolyticus становив 42,8 \% серед усіх виявлених мікроорганізмів при первинному обстеженні дитини, та при повторному дослідженні виявлено приріст цього мікроорганізму на 7,3 \%.

Streptococcus групи viridans, так само, як і Staphylococcus aureus, при повторному дослідженні дещо зменшили свою частку порівняно з даними первинних посівів, проте відсотковий вміст коринебактерій збільшився під час перебування дитини у відділенні анестезіології та інтенсивної терапії новонароджених дітей порівняно з первинними посівами. Частка Streptococcus agalactiae та Enterococcus faecium як у первинних, так і в повторних посівах із верхніх дихальних шляхів майже не змінилась, але у випадку з ентерококом спостерігався незначний приріст, а із стрептококом - незначне зменшення проценту вмісту серед інших мікроорганізмів. Серед грамнегативних мікроорганізмів у посівах із верхніх дихальних шляхів пацієнтів переважала Klebsiella pneumoniae, але в повторних дослідженнях її кількість незначно зменшилась, ніж при госпіталізації до стаціонару, 16,1 та 13,0 \% відповідно. Майже не змінили своєї частки Enterobacter cloacae на всіх етапах дослідження, як і Pseudomonas aeruginosa, частка яких при первинному дослідженні дорівнювала 3,4 \%, а під час перебування дитини на лікуванні у відділенні становила 4,4 \%. Виявлене збільшення вмісту Acinetobacter baumannii з 2,0 \% при госпіталізації дитини до стаціонару до 6,3 \% при проведенні повторних посівів.

Аналізуючи дані первинних посівів біологічного матеріалу пацієнтів за 2019 рік, з'ясовано, що чутливість грампозитивних мікроорганізмів до ванкоміцину, карбапенемів та лінезоліду стовідсоткова, трохи нижча чутливість до амікацину, ципрофрлоксацину, кліндаміцину та піперациліну/тазобактаму (84,1-89,7 \%) (рис. 1).

Достатню чутливість щодо грампозитивної фрлори при первинному дослідженні пацієнта продемонстрували гентаміцин - 70,5 \%, тикарцилін/клавуланат - 69,3 \%, цефтазидим та ампіцилін - по 67,4 \%, ледь перетнув $50 \%$ межу цефтріаксон. Інші досліджувані антибактеріальні препарати не виявили високої чутливості до грампозитивних мікроорганізмів при проведенні пер- винних посівів. При повторних дослідженнях чутливості грампозитивних мікроорганізмів до антибактеріальних препаратів з'ясовано, що зберігається висока чутливість до ванкоміцину, лінезоліду, іміпенему, ертапенему та кліндаміцину (75-100 \%). Чутливість, що перевищує 50 \%, властива ампіциліну, амікацину, ципрофлоксацину, піперациліну/тазобактаму та карбапенемам.

Грамнегативна фрлора протягом усього періоду дослідження при первинному обстеженні виявилася високочутливою до сучасних захищених пеніцилінів (піперациліну/тазобактаму), карбапенемів, аміноглікозидів, срторхінолонів (рис. 2).

Майже 72 \% грамнегативних мікроорганізмів виявили чутливість до цефралоспоринів, чутливість до амоксиклаву та тикарциліну/клавуланату трохи перевищувала $60 \%$. При проведенні дослідження чутливості грамнегативних мікроорганізмів у повторних посівах із верхніх дихальних шляхів пацієнтів виявлено, що досить високу чутливість зберігають карбапенеми (75-84,4 \%). Чутливість до аміноглікозидів у повторному дослідженні зменшилась, але перевищувала $50 \%$ рівень чутливості і становила 57,7 \% у гентаміцину, 76,5 \% у амікацину та до ципрофлоксацину 56,8 \%. Також суттєво знизилась чутливість до інгібіторозахищених пеніцилінів. Серед препаратів із високою чутливістю деякі антибіотики заборонені до використання при лікуванні новонароджених дітей.

Про переважання грампозитивних бактерій у відділеннях інтенсивної терапії новонароджених дітей свідчать дослідження, проведені деякими дослідниками [8, 9, 11-13, 26], але деякі літературні джерела доповідають про протилежну тенденцію у реанімаційних відділеннях загального профрілю $[2,5,8,16]$.

Схожу достатньо високу чутливість патогенної грампозитивної мікрофрлори засвідчують деякі дослідники до глікопептидів, оксазолідинонів, фторхінолонів та бета-лактамних пеніцилінів [1, 2, 6, 14, 19-21]. За літературними даними, грамнегативні мікроорганізми чутливі до деяких цефралоспоринів [1, 6, 17], до яких у нашому дослідженні кращу чутливість патогенів виявлено лише при первинному обстеженні.

Деякі антибактеріальні препарати, такі як гентаміцин, іміпенем, поновлюють чутливість до патогенних мікро-

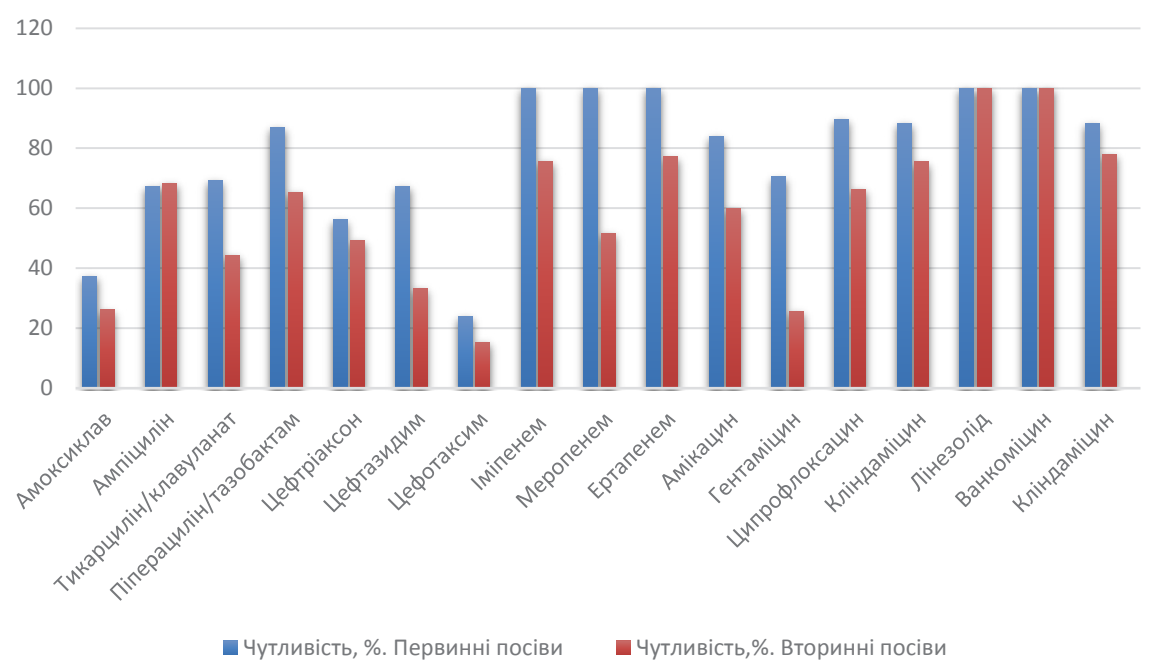

Рис. 1. Дані чутливості грампозитивної срлори до антибіотиків. 


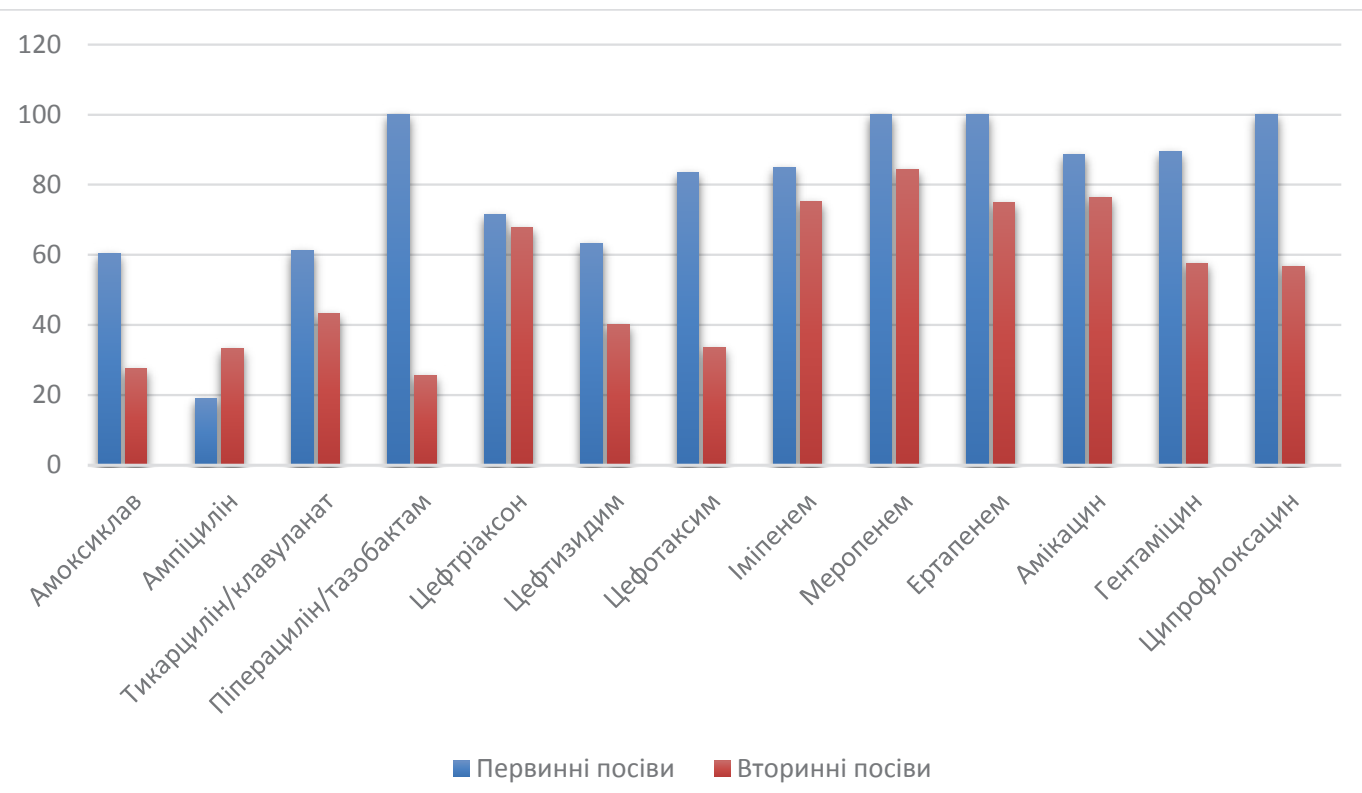

Рис. 2. Дані чутливості грамнегативної фрлори до антибіотиків.

організмів та знаходять більш широке застосування у відділеннях інтенсивної терапії [5, 10].

Висновки. 1. Як первинна, так і нозокоміальна мікрофрлора дихальних шляхів хворих характеризується явним переважанням грампозитивних мікроорганізмів протягом усього дослідження.

2. Достатню чутливість грампозитивних патогенів виявили до ванкоміцину, карбапенемів, лінезоліду, амікацину, ципрофлоксацину, кліндаміцину та піперациліну/тазобактаму при первинному дослідженні, а при повторному дослідженні відмічається висока чутливість до ванкоміцину, лінезоліду, іміпенему, ертапенему та кліндаміцину.

3. При первинному дослідженні чутливості грамнегативної мікрофлори до антибіотиків виявилась висока чутливість до сучасних захищених пеніцилінів (піпе- рациліну/тазобактаму), карбапенемів, аміноглікозидів, фрторхінолонів, а при дослідженні чутливості у повторних посівах із верхніх дихальних шляхів пацієнтів виявлено, що досить високу чутливість зберігають карбапенеми та аміноглікозиди.

4. Застосування антибактеріальної терапії з урахуванням чутливості фрлори є запорукою більш швидкого покращення клініко-біологічних показників пацієнта і, як наслідок, скорочення терміну перебування у відділенні інтенсивної терапії.

ПЕРСПЕКТИВИ ПОДАЛЬШИХ ДОСЛІДЖЕНЬ. На підставі аналізу даних мікробіологічних досліджень визначити швидкість фрормування резистентності штамів патогенних мікроорганізмів.

Конфлікт інтересів. Автори заявляють про відсутність консрлікту інтересів при підготовці даної статті.

\section{СПИСОК ЛІТЕРАТУРИ}

1. Внутрішньолікарняне інорікування новонароджених, які перебувають у відділенні інтенсивної терапії: залежність від гестаційного віку / О. С. Яблонь, І. І. Ремінна, О. А. Моравська [та ін.] // Неонатологія, хірургія та перинатальна медицина. - 2016. - T. VI, № 4 (22). - C. 17-22.

2. Еволюція мікробного пейзажу та сучасні тенденції формування антибіотикорезистентності в патогенної мікрофрлори відділень інтенсивної терапії загального профрілю / М. В. Бондар, М. М. Пилипенко, Л. А. Харченко [та ін.] // Медицина неотложных состояний. - 2017. - № 1 (80). C. 102-105. doi: 10.22141/2224-0586.1.80.2017.94460

3. Antibiotics prescriptions in the neonatal intensive care unit: how to overcome everyday challenges / D. Donna, E. Mozzo, V. Margedan [et al.] // Am. J. Perinatol. - 2017. - Vol. 34 (12). - P. 1169-1177. DOI: 10.1055/s-0037-1602426.

4. Раціональне застосування антибіотиків при інфекціях дихальних шляхів в амбулаторній практиці / Л. В. Хіміон, О. Б. Ященко, С. В. Данилюк, Т. О. Ситюк // Семейная медицина. - 2017. - № 2 (70). - С. 40-48.

5. Пилипенко М. М. Поєднання карбапенемрезистент- ності та колістинрезистентності збудників тяжких грамнегативних нозокоміальних інфекцій: перші ознаки настання постантибіотичної ери / М. М. Пилипенко, Т. В. Овсієнко, М. В. Бондар // Медицина невідкладних станів. - 2019. № 2 (97). - C. 54-62. doi: 10.22141/2224-0586.2.97.2019.161643.

6. Evaluation of antimicrobial consumption in a neonatelogy unit: a team work to promote the rational use of antibiotics / E. Jiménez, N. Valls, P. Astudillo [et al.] // Rev. Chilena Infectol. - 2017. - Vol. 34 (6). - P. 544-552. DOI: 10.4067/S071610182017000600544.

7. Cotten Ch. M. Adverse consequences of neonatal antibiotic exposure / Ch. M. Cotten // Current Opinion in Pediatrics. - 2016. - Vol. 28 (2). - P. 141-149. DOI: 10.1097/ MOP.0000000000000338.

8. Сравнительный анализ микроорганизмов, выделенных от больных в отделениях реанимации разного профиля / М. И. Петрухина, А. М. Мартынова, Н. Г. Политова [и др.] // Медицинский альманах. - 2016. - № 3 (43). - С. 17-20.

9. Healthcare associated infections in neonatal intensive care unit and its correlation with the environmental surveillance / 
S. Kumar, B. Shankar, S. Arya, [et al.] // Journal of infection and Public Health. - 2018. - Issue 2, Vol. 11. - P. 275-279. DOI: $10.1016 / j . j i p h .2017 .08 .005$.

10. What do I need to know about aminoglycoside antibiotics? / E. Germovsek, C. I Barker, M. Sharland // Arch. Dis. Child. Educ. Pract. Ed. - 2017. - Vol. 102 (2). - P. 89-93. DOI: 10.1136/archdischild-2015-309069.

11. Bacteriological profile and antibiotic susceptibility of neonatal sepsis in neonatal intensive care unit of a tertiary hospital in Nepal / B. Pokhrel, T. Koirala, G. Shah [et al.] // BMC Pediatrics Journal. - 2018. - Vol. 18 (1). - P. 208. DOI: 10.1186/ s12887-018-1176-x.

12. Epidemiology of UK neonatal infections: the neonIN infection surveillance network / B. Cailes, C. Kortsalioudaki, J. Buttery [et al.] // Archives of Disease in Childhood. Fetal and Neonatal Edition. - 2018. - Vol. 103 (6). - P. 547-553. DOI: 10.1136/archdischild-2017-313203.

13. Reduced nosocomial infection rate in a neonatal intensive care unit during a 4- year surveillance period / Y.-C. Chen, C.-F. Lin, Y.-J. Fuh Rehn [et al.] // Journal of the Chinese Medical Association. - 2017. - Vol. 80 (7). - P. 427-431. DOI: 10.1016/j.jcma.2017.02.006.

14. Colistin alone versus colistin plus meropenem for treatment of severe infections caused by carbapenem-resistant Gram-negative bacteria: an open-label, randomised controlled trial / M. Paul, G.L Daikos, E. Durante-Mangoni [et al.] // Lancet Infect. Dis. - 2018. - Vol. 18 (4). - P. 391-400. DOI: 10.1016/ S1473-3099(18)30099-9.

15. Control of Gram-negative multi-drug resistant microorganisms in an Italian ICU: rapid decline as a result of a multifaceted intervention, including conservative use of antibiotics / A. Frattari, V. Savini, E. Polilli [et al.] // Int. J. Infect. Dis. - 2019. - Vol. 84. - P. 153-162. DOI: 10.1016/j.ijid.2019.04.002.

16. Microbiological analysis of endotracheal aspirate and endotracheal tube cultures in mechanically ventilated patients / L. Shen, F. Wang, J. Shi [et al.] // BMC Pulm. Med. - 2019. Vol. 19 (1). DOI: 10.1186/s12890-019-0926-3.

17. Ceftaroline for suspected or confirmed invasive methicillin-resistant Staphylococcus aureus: a pharmacokinetic case series / J. J. Cies, W. S. Moore, A. Enache, A. Chopra // Pediatr.
Crit. Care Med. - 2018. - Vol. 19 (6). - P. 292-299. DOI: 10.1097/ PCC. 0000000000001497.

18. Intensive care management of children intubated for croup: a retrospective analysis / B. Gelbart, S. Parsons, A. Sarpal [et al.] // Anaesth Intensive Care. - 2016. - Vol. 44 (2). P. 245-250. DOI: 10.1177/0310057X1604400211.

19. A nonclonal outbreak of vancomycin-sensitive Enterococcus faecalis bacteremia in a neonatal intensive care unit / D. Kotsanas, K. Tan, C. Scott [et al.] // Infect. Control Hosp. Epidemiol. - 2019. - Vol. 40 (10). - P. 1116-1122. DOI: $10.1017 /$ ice.2019.202.

20. $\beta$-lactam therapeutic drug management in the PICU / J. J. Cies, W.S. Moore, A. Enache, A. Chopra // Crit. Care Med. - 2018. - Vol. 46 (2). - P. 272-279. DOI: 10.1097/ CCM.0000000000002817.

21. Beta-lactam antibiotics in critically ill patients-guidelines from the French Society of Pharmacology and Therapeutics (Société Française De Pharmacologie Et Thérapeutique-SFPT) and the French Society of Anaesthesia and Intensive Care Medicine (Société Française d'Anesthésie Et RéanimationSFAR) / R. Guilhaumou, S. Benaboud, Y. Bennis [et al.] // Crit. Care. - 2019. - Vol. 23 (1). DOI: 10.1186/s13054-019-2378-9.

22. Campion M. Antibiotic use in the intensive care unit: Optimization and de-escalation / M. Campion, G. Scully // J. Intensive Care Med. - 2018. - Vol. 33 (12). - P. 647-655. DOI: $10.1177 / 0885066618762747$.

23. Antibiotic strategies in the era of multidrug resistance / G. Karam, J. Chastre, M. H. Wilcox, J. L. Vincent // Crit Care. 2016. - Vol. 20 (1). DOI: 10.1186/s13054-016-1320-7.

24. Role of antimicrobial stewardship programmes in children: a systematic review / A. R. Araujo da Silva, D. C. Albernaz de Almeida Diaz, A. F. Marquaes [et al.] // J. Hosp. Infect. - 2018. - Vol. 99 (2). - P. 117-123. DOI: 10.1016/j.jhin.2017.08.003.

25. Shime N. Antimicrobials in the PICU: an unresolved and serious matter / N. Shime // Pediatr. Crit Care Med. - 2018. Vol. 19 (6). - P. 581-582. DOI:10.1097/PCC.0000000000001544.

26. Seliem W. A. Etiology of early onset neonatal sepsis in neonatal intensive care unit - Mansoura, Egypt / W. A. Seliem, A. M. Sultan // J. Neonatal Perinatal Med. - 2018. - No. 11 (3). - P. 323-330. DOI: 10.3233/NPM-17128.

\section{REFERENCES}

1. Yablon, O.S., Reminna, I.I., Moravska, O.A., Bertsun, K.T., \& Chekotun, T.V. (2016). Vnutrishnolikarniane infikuvannia novonarodzhenykh, yaki perebuvaiut u viddilenni intensyvnoi terapii: zalezhnist vid hestatsiinoho viku [Nosocomial infection of newborns in the intensive care unit: dependence on gestational age]. Neonatolohiia, khirurhiia ta perynatalna medytsyna - Neonatology, Surgery and Perinatal Medicine, VI, 4 (22), 17-22 [in Ukrainian].

2. Bondar, M.V., Pylypenko, M.M., Kharchenko, L.A., Ovsiyenko, T.V., Domoratskyi, O.E., Svintukovskyi, M.Yu., ..., \& Shmorhun, V.V. (2017). Evoliutsiia mikrobnoho peizazhu ta suchasni tendentsii formuvannia antybiotykorezystentnosti $v$ patohennoi mikroflory viddilen intensyvnoi terapii zahalnoho profiliu [Evolution of the microbial landscape and current trends of antibiotic resistance formation in pathogenic microrganisms in general intensive care units]. Medytsyna neotlozhnykh sostoyaniy - Emergency Medicine, 1 (80), 102-105. DOI: 10.22141/2224-0586.1.80.2017.94460.

3. Donà, D., Mozzo, E., Mardegan, V., Trafojer, U., Lago, P., Salvadori, S., ..., \& Giaquinto, C. (2017). Antibiotics prescriptions in the neonatal intensive care unit: how to overcome everyday challenges. Am. J. Perinatol., 34 (12), 1169-1177. DOI: 10.1055/s-0037-1602426.
4. Khimion, L.V., Yaschenko, O.B., Danyliuk, S.V., \& Sytiuk, T.O. (2017). Ratsionalne zastosuvannia antybiotykiv pry infektsiiakh dykhalnykh shliakhiv $v$ ambulatornii praktytsi [Rational use of antibiotics in respiratory infections in outpatient practice]. Semeynaya meditsyna - Family Medicine, 2 (70), 40-48 [in Ukrainian].

5. Pylypenko, M.M., Ovsiienko, T.V., \& Bondar, M.V. (2019). Poiednannia karbapenemrezystentnosti ta kolistynrezystentnosti zbudnykiv tiazhkykh hramnehatyvnykh nozokomialnykh infektsii: pershi oznaky nastannia postantybiotychnoi ery [Combination of carbapenemresistance and colistinresistance of pathogens of severe gram-negative nosocomial infections: the first signs of the postantibiotic era]. Medytsyna nevidkladnykh staniv - Emergency Medicine, 2 (97), 54-62. DOI: 10.22141/22240586.2.97.2019.161643

6. Jiménez, E., Valls, N., Astudillo, P., Valls, C., Cavada, G., Sandoval, A., ..., \& Mena, P. (2017). Evaluation of antimicrobial consumption in a neonatelogy unit: a team work to promote the rational use of antibiotics. Rev. Chilena Infectol., 34 (6), 544-552. DOI: $10.4067 /$ S0716-10182017000600544.

7. Cotton, C.M. (2016). Adverse consequences of neonatal antibiotic exposure. Current Opinion in Pediatrics, 28 (2), 141149. DOI: 10.1097/MOP.0000000000000338. 
8. Petruhina, M.I., Martynova, A.M., Politova, N.G., Jushhenko, G.V., \& Starostina, N.V. (2016). Sravnitelnyi analiz mikroorganizmov, vydelennyh ot bolnyh $v$ otdeleniiah reanimacii raznogo profilia [Comparative analysis of microorganisms isolated from patients in intensive care units of different profiles]. Meditsinskiy almanakh - Medical Almanac, 3 (43), 17-20 [in Russian].

9. Kumar, S., Shankar, B., Arya, S., Deb, M., \& Chellani, H. (2018). Healthcare associated infections in neonatal intensive care unit and its correlation with the environmental surveillance. Journal of Infection and Public Health, 2, 11, 275-279. DOI: 10.1016/j.jiph.2017.08.005.

10. Germovsek, E., Barker, C.I., \& Sharland, M. (2017). What do I need to know about aminoglycoside antibiotics? Arch. Dis. Child Educ. Pract. Ed., 102 (2), 89-93. DOI: 10.1136/ archdischild-2015-309069.

11. Pokhrel, B., Koirala, T., Shah, G., Joshi, S., \& Baral, P. (2018). Bacteriological profile and antibiotic susceptibility of neonatal sepsis in neonatal intensive care unit of a tertiary hospital in Nepal. BMC Pediatrics Journal, 18 (1), 208. DOI: 10.1186/ s12887-018-1176-X.

12. Cailes, B., Kortsalioudaki, C., Buttery, J., Pattnayak, S., Greenough, A., Matthes, J., ..., \& Heath, P.T. (2018). Epidemiology of UK neonatal infections: the neonIN infection surveillance network. Archives of Disease in Childhood. Fetal and Neonatal Edition, 103 (6), 547-553. DOI: 10.1136/ archdischild-2017-313203.

13. Chen, Y.-C., Lin, C.-F., Fuh Rehn, Y.-J., Chen, J.-C., Chen, P.-Y., Chen, C.-H. ..., \& Huang, F.-L. (2017). Reduced nosocomial infection rate in a neonatal intensive care unit during a 4- year surveillance period. Journal of the Chinese Medical Association, 80 (7), 427-431. DOI: 10.1016/j.jcma.2017.02.006.

14. Paul, M., Daikos, G.L., Durante-Mangoni, E., Yahav, D., Carmeli, Y., Dishon Benattar, Y., \& L. Leibovici. (2018). Colistin alone versus colistin plus meropenem for treatment of severe infections caused by carbapenem-resistant Gram-negative bacteria: an open-label, randomised controlled trial. Lancet Infect. Dis., 18 (4), 391-400. DOI: 10.1016/S1473-3099(18)30099-9.

15. Frattari, A., Savini, V., Polilli, E., Di Marco, G., Lucisano, G. Corridoni, S., ..., \& Parruti, G. (2019). Control of Gram-negative multi-drug resistant microorganisms in an Italian ICU: rapid decline as a result of a multifaceted intervention, including conservative use of antibiotics. Int. J. Infect. Dis., 84, 153-162. DOI: 10.1016/j.ijid.2019.04.002.

16. Shen, L., Wang, F., Shi, J., Xu, W., Jiang, T., Tang, H., ..., \& Chang, Q. (2019). Microbiological analysis of endotracheal aspirate and endotracheal tube cultures in mechanically ventilated patients. BMC Pulm. Med., 19 (1). DOI: 10.1186/ s12890-019-0926-3.

17. Cies, J.J., Moore, W.S., Enache, A., \& Chopra, A. (2018). Ceftaroline for suspected or confirmed invasive methicillinresistant Staphylococcus aureus: a pharmacokinetic case series. Pediatr. Crit. Care Med., 19 (6), 292-299. DOI: 10.1097/ PCC.0000000000001497.

18. Gelbart, B., Parsons, S., Sarpal, A., Ninova, P., \& Butt, W. (2016). Intensive care management of children intubated for croup: a retrospective analysis. Anaesth Intensive Care, 44 (2), 245-250. DOI: 10.1177/0310057X1604400211.

19. Kotsanas, D., Tan, K., Scott, C., Baade, B., Hui Ling Cheng, M., Tan, Z.V., ..., \& Stuart, R.L. (2019). A nonclonal outbreak of vancomycin-sensitive Enterococcus faecalis bacteremia in a neonatal intensive care unit. Infect. Control Hosp. Epidemiol., 40 (10), 1116-1122. DOI: 10.1017/ice.2019.202.

20. Cies, J.J., Moore, W.S., Enache, A., \& Chopra, A. (2018). $\beta$-lactam therapeutic drug management in the PICU. Crit. Care Med., 46 (2), 272-279. DOI: 10.1097/CCM.0000000000002817.

21. Guilhaumou, R., Benaboud, S., Bennis, Y., DahyotFizelier, C., Dailly, E., Gandia, P., ..., \& Garnier, M. (2019). Optimization of the treatment with Beta-Lactam antibiotics in critically ill patients-guidelines from the french society of pharmacology and therapeutics (Société Française De Pharmacologie Et Thérapeutique-SFPT) and the French Society of Anaesthesia and Intensive Care Medicine (Société Française d'Anesthésie Et Réanimation-SFAR). Crit. Care, 23 (1). DOI: 10.1186/s13054019-2378-9.

22. Campion, M., \& Scully, G. (2018). Antibiotic use in the intensive care unit: optimization and de-escalation. J. Intensive Care Med., 33 (12), 647-655. DOI: 10.1177/0885066618762747.

23. Karam, G., Chastre, J., Wilcox, M.H., \& Vincent, J.L. (2016). Antibiotic strategies in the era of multidrug resistance. Crit. Care., 20 (1). DOI: 10.1186/s13054-016-1320-7

24. Araujo da Silva, A.R., Albernaz de Almeida Dias, D.C., Marques, A.F., Biscaia di Biase, C., Murni, I.K., Dramowski, A., ..., \& Zingg, W. (2018). Role of antimicrobial stewardship programmes in children: a systematic review. J. Hosp. Infect., 99 (2), 117-123. DOI: 10.1016/j.jhin.2017.08.003.

25. Shime, N. (2018). Antimicrobials in the PICU: an unresolved and serious matter. Pediatr. Crit. Care Med., 19 (6), 581-582 DOI:10.1097/PCC.0000000000001544.

26. Seliem, W.A., \& Sultan, A.M. (2018). Etiology of early onset neonatal sepsis in neonatal intensive care unit Mansoura, Egypt. J. Neonatal Perinatal Med., 11 (3), 323-330. DOI: $10.3233 /$ NPM-17128.

Отримано 29.05.20 Прийнято до друку 23.06.20

Електронна адреса для листування: ketaminum@gmail.com 